\title{
IAMJ
}

INTERNATIONAL

AYURVEDIC

MEDICAL JOURNAL

ISSN: 2320-5091

Impact Factor: 6.719

\section{A ROLE OF JALUAKAAVCHARANAAND NIMBA HARIDRACHOORNA LEPA IN TREATMENT OF INDRALUPTA - A CASE STUDY}

\section{$\underline{\text { Sejalgamit }}$}

Assistant Professor Department of Shalyatantra, Shree Swaminarayan Ayurved

College, Kalol, Gandhinagar, Gujarat, India

Corresponding Author: dr.sejalgamit@gmail.com

https://doi.org/10.46607/iamj2409062021

(Published Online: June 2021)

Open Access

(C) International Ayurvedic Medical Journal, India 2021

Article Received:28/05/2021 - Peer Reviewed:09/06/2021 - Accepted for Publication:10/06/2021

Check for updates

\begin{abstract}
Hair is crowning glory and mark of identity of human being. Indralupata in modern science correlate with alopecia aereata. It is characterized by localised areas of non-scarring hair loss which can be co-related with indralupta. Due to side effects and limitation of contemporary science, some harmless and effective medicines are expected from alternative medical science. indralupta disease is described under heading of kshudraroga by sushruta, vagbhata etc.in modern science its main treatment is corticosteroids which is having harmful side effects and not advisable for long term use.so it is necessary to find better remedies .it can be easily fulfilled by Ayurveda. Here, a case of female patient suffering from indralupta was successfully treated with jaluaka and haridra and nimbalepa.
\end{abstract}

Keywords: kshudraroga, indralupta, jaluaka, haridra and nimbalepa

\section{INTRODUCTION}

Hair is crowning glory of human being. In present era lifestyle changes in food habits and mental stress etc. Hair loss problems are increasing. Alopeciaareata is an autoimmune disease characterized by hair loss on body especially on scalp without any clinical inflammatory signs. ${ }^{1}$ its prevalence in general 
population was estimated at $0.1-0.2 \%$ wih a lifetime risk of $1.7 \% .{ }^{2}$ Male was reported to be more affected with the disease in comparison to children and women, but it is cause more emotional problems in women and children due to cosmetic concern. ${ }^{3}$ its main treatment in modern science is corticosteroids which is having harmful side effects and not advisable for long time use. ${ }^{4}$ in Ayurveda different type of treatment modalities are available for different type of auto immune diseases. Indralupta can be correlate with alopecia areata, Indralupta disease described in Ayurveda under heading of kapalgata roga $a^{4}$.by acharyavagbhata and kshudraroga by acharyamadhavnidan, yogaratnakar and sushruta ${ }^{5}$, indralupta is characterised by patchy hair loss. pitta associated with vata gets lodged in romkupa and causes hair fall, later on kaphadosha associated with rakta causes obstruction to the hair roots and restricted the regrowth. Raktamokshana is indicated in Raktajvyadhi that helps in draining the DushitaRakta, in turns plays an important role in sampraptivighatana of indralupta. Haridra is strong anti-bacterial, antiallergic properties ${ }^{6}$. Nimba have numerous biological and pharmacological activities have been reported including antibacterial ${ }^{7}$, antifungal ${ }^{8}$, and antiinflammatory.

\section{Objective}

To find out the efficacy of Jaluakaavcharana and nimbaharidrachoornalepa in management of indralupta

\section{Case Report}

A 21 year old female patient visited to Swaminarayan ayurvedic hospital with complaints of patchy hair loss since 8 month with hair fall , and itching at patchy hair loss area ,he was apply some home remedies oil but there was no improvement in her symptoms ,so she come to our hospital for further management. Jalouakaavcharana was done at patchy hair loss area interval of seven days, that is, on day 1, 7 day, 14 day and 21 days without internal medication and nimbaharidaralepa was done locally patchy hair loss area 21 days once in a days.

\section{Methodology}

\section{Purva Karma}

Cleaning a site of patchy hair loss area before leech was applying. Then leech was put in water mixed turmeric powder for purification of leech and then put in normal water.

\section{Pradhan karma}

Then Jaluaka was applying at site of patchy hair loss area. While sucking the blood following signs appears in the body of leech a. Gradual distension in the central portion of the body. b. Itching and burning sensation at the site of bite. c. Pulsations on the body of leech may be visible. After application of Jaluaka Leech through its front end and covers the leech by wet cotton. Removal of Leech After 30- 45 minutes the leech is removed by itself, or by application of turmeric powder on the mouth of leech.

\section{Paschat karma}

After removal of Jaluaka pt. dressing with Haridra powder Churna and bandage was applied. Vamana karma of leech was done. Haridranimbalepa After 30-minute of jalouakaavcharana, haridra powder nimbapatralepa was applied at patchy hair loss area.

\section{RESULT}

In this case, improvement was seen in itching sensation, patchy hair loss area was covered with new hair growth. Haridra $\mathrm{n}$ nimbapatra local application are useful for itching sensation in scalp. Jaluaka Avcharana was effective these treatment modalities taken for the study were having local action. When the treatment started the patient had one patch of hair loss in the mid scalp region [Figure 1]. After two sittings of Jalaukavacharana, very small white hairs started to grow from the hair follicles in that patch. Significant growth in the length of hairs was noticed after 4sittings. Also, the color of the hairs changed from white to black, haridra powder nimbapatralepa was applied at patchy hair loss area. After completion of 30 minutes Jalaukavacharana[Figure 3].the patch was partially covered with hairs. The patch was small and was partially filled with lustrous black hair at the end of the follow-up period [Figure 4] and itching was completely gone. 


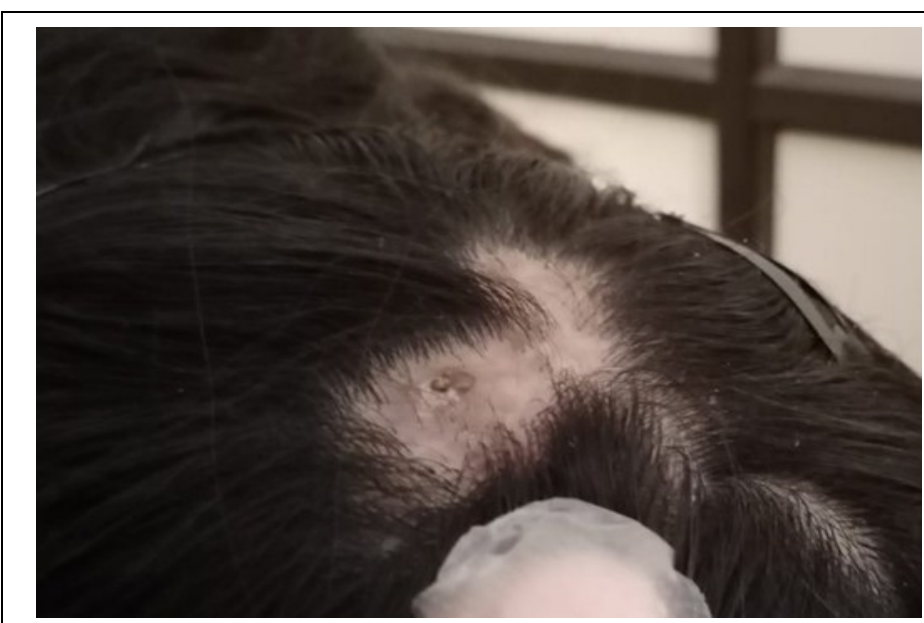

Figure 1: Before treatment

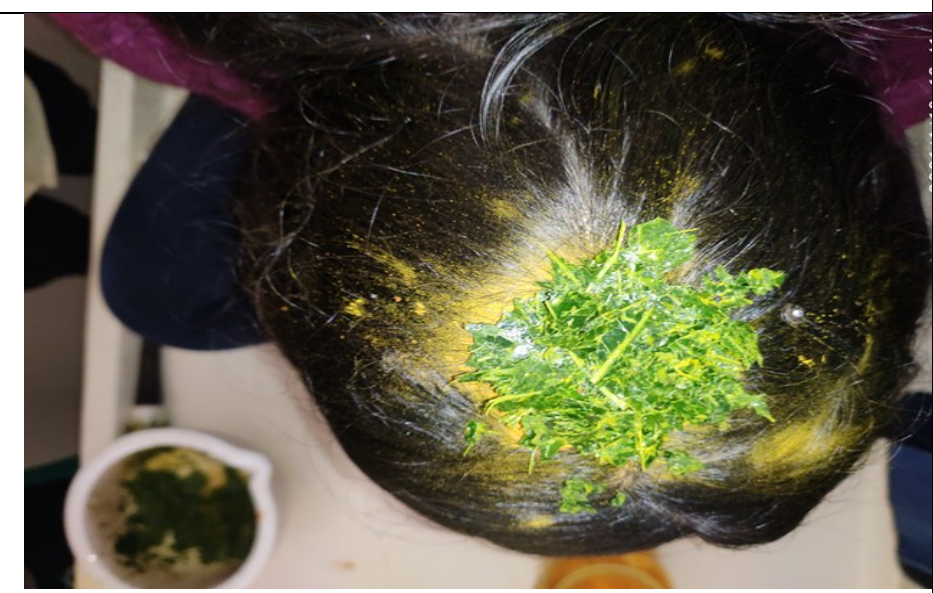

Figure 3: Haridra-nimbapatralepa

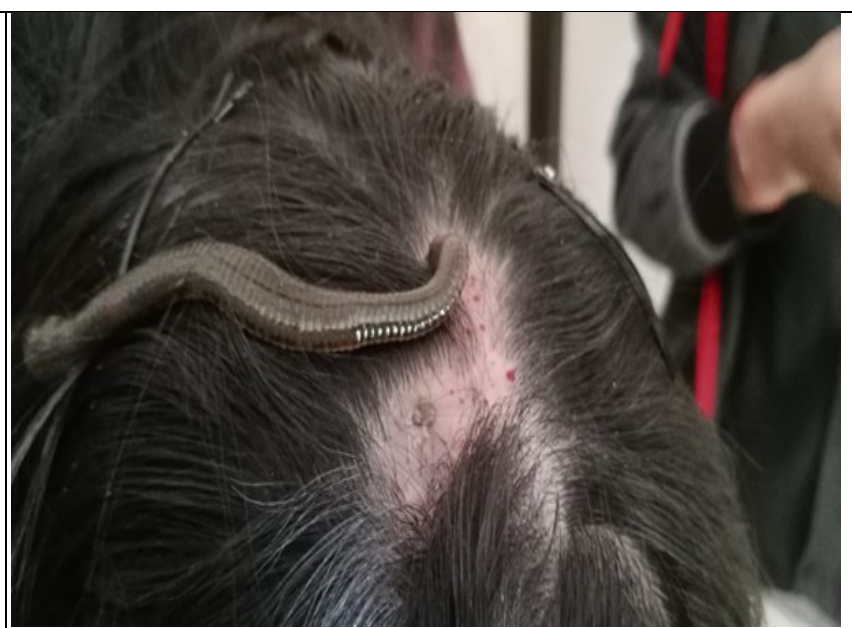

Figure 2: During jaloukaavacharana

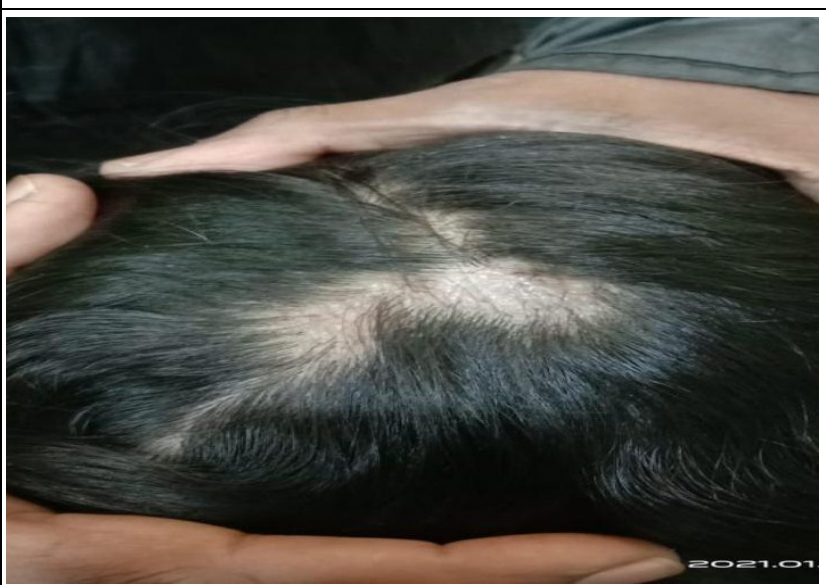

Figure 4: After complete treatment of

Jaloukaavacharana

\section{DISCUSSION}

In the present case diagnosis of Aelopeciaaerata or Indralupta was made based on clinical presentation. The patient was VataPittajin Prakriti with Pitta Vardhak dietary habits. She was used to having junk food frequently and the patient had the habit of day sleeping. Indralupta is a condition mentioned by Acharya Sushruta in which the deranged Vata and Pitta having recourse to the roots of the hairs bring about their gradual falling off, while the deranged

Rakta and Kapha of the locality fill up those pores or holes, thus barring their fresh growth and recrudescence ${ }^{9}$. Here, Leech therapy is an ideal method for Raktamokshana (bloodletting) in blood vitiated by Pitta and also for females, children, and old age persons. Leeches have more than 20 bioactive molecules in their secretions. These molecules have analgesic, anti-inflammatory, platelet inhibitory, anticoagulant, and thrombin regulatory

functions, as well as extracellular matrix degradative and antimicrobial effects ${ }^{10}$.

In Alopecia aeratea leech therapy may have worked by increasing the microblood circulation through acetylcholine- and histamine-like molecule. Leech saliva also contains Destabilase and chloromycetin which have an antimicrobial effect ${ }^{11}$. When leech therapy is done on thinning or bald areas, the increase of blood circulation helps enhance the concentration and delivery of nutrients to that area on one side and removal of accumulated toxin, inflammatory 
substances on the other side thereby assisting in the promotion of hair growth. Haridra (curcumalonga) has excellent Raktaprasadaka (Bloodpurifier), Raktastambhaka (Hemostatic Raktaprasadaka (Bloodpurifier), Raktastambhaka (Hemostatic), Vedanasthapka (Analgesic) properties ${ }^{12}$. Soharidra was excellent for scalp cleanliness and itching sensation. tikta rasa has kandughna property and also Nimba is a kandughnadrug. ${ }^{13}$

\section{CONCLUSION}

Alopecia aereata is a very common problem these days seen in youngsters. It can be correlated with Indralupta according to its signs and symptoms. According to the Avastha of the Doshas, leech therapy sittings showed a promising effect on this case of Alopeci Aaereata of a female patient. Hence, if done on a large scale, this treatment can be a successful management for alopecia whose sure-shot management is not known till now

\section{REFERENCES}

1. Bansal M, Manchanda K, Pandey SS. Annular alopecia areata report of two cases. Int J Trichol2013; 5:91-3.

2. Hunter JAA. Clinical Dermatology, Regional Dermatology, Chapter 13, 3rd ed. USA: Blackwell Publishing; p. 164.

3. Hashtri A. Vyadhisammudeshiyam Adhyaya. Sutrasthana 24/11. In:-Shri Dalhanaacharaya, Sushrut. Susruta Samhita of Maharsi Susruta. Ayurveda Tattva Sandipika Hindi Commentary, Chaukhamba Sanskrit Sansthan, Varanasi; 2010.p. 132.

4. Shashtri A. Kshudraroganamnidanam Adhyaya. Nidanasthana13/34. In: Shri Dalhanaacharaya, Sushrut. Susruta Samhita of

5. Mahars iSusruta. Ayurveda Tattva Sandipika Hindi Commentary, Chaukhamba Sanskrit Sansthan, Varanasi; 2010.p. 368.

6. Shashtri A. Jaloukavacharniya Adhyaya. Sutrasthana 13/3. In: Shri Dalhanaacharaya, Sushrut. Susruta Samhita of Maharsi Susruta. Ayurveda Tattva Sandipika Hindi Commentary, Chaukhamba Sanskrit Sansthan, Varanasi; 2010. p. 57

7. Singh N., Sastry M. S. Antimicrobial activity of Neem oil. Indian Journal of Pharmacology. 1997; 13:102106.
8. Kher A., Chaurasia S. C. Antifungal activity of essential oils of three medical plants. Indian Drugs. 1997; 15:41-42.

9. Shashtri A. Kshudraroganidanaadhyaya. Nidanasthana 13/32-3. In: Shri Dalhanaacharaya, Sushrut. Susruta Samhita of Maharsi Susruta. Ayurveda Tattva Sandipika Hindi Commentary, Chaukhamba Sanskrit Sansthan, Varanasi; 2010.p. 368.

10. A M Abdualkader, A M Ghawi, M Alaama, M Awang, A Merzouk. Leech Therapeutic Applications Indian J Pharm Sci. 2013 Mar;75(2):127-37.

11. Sig AK, Guney M, UskudarGuclu A, Ozmenet E. Medicinal leech therapy-An overall perspective. Integr Med Res 2017; 6:337-43.

12. Kaviraja Ambikadutt Shastri.(2011).Sushrutasamhita, (Vol-1) Varanasi;

ChaukhambaSanskritsansthan;Pageno.205.

13. SastryJLN. Dravya Gunavijnana Vol II.2 ${ }^{\text {nd }}$ ed. Varanasi: chaukhamba Orientalia; 2005.p.125.s

\section{Source of Support: Nil \\ Conflict of Interest: None Declared}

How to cite this URL: Sejalgamit et al: A Role Of Jaluakaavcharanaand Nimba Haridrachoorna Lepa In Treatment Of Indralupta - A Case Study. International Ayurvedic Medical Journal \{online\} 2021 \{cited June, 2021\} Available from: http://www.iamj.in/posts/images/upload/1299_1302.pdf 